Original scientific paper - Izvorni znanstveni rad

UDK: 637.112 .2

\title{
The influence of feed supplementation with linseed oil and linseed extrudate on fatty acid profile in goat yoghurt drinks
}

doi: $10.15567 /$ mljekarstvo.2018.0104

\author{
Markéta Borková ${ }^{*}$, Miloslav Šulc ${ }^{2}$, Klára Novotná ${ }^{3}$ Jana Smolová ${ }^{1}$ \\ Ivana Hyršlová ${ }^{1}$, Milena Fantová ${ }^{3}$, Ondřej Elich ${ }^{1}$ \\ ${ }^{1}$ Dairy Research Institute, Ke Dvoru 12a, 16000 Prague, Czech Republic \\ ${ }^{2}$ Czech University of Life Sciences Prague, Faculty of Agrobiology, Food and Natural Resources, \\ Department of Chemistry, Kamýcká 129, 16500 Prague, Czech Republic \\ ${ }^{3}$ Czech University of Life Sciences Prague, Faculty of Agrobiology, Food and Natural Resources, \\ Department of Animal Husbandry, Kamýcká 129 16500, Prague, Czech Republic
}

Received - Prispjelo: 02.06.2017. Accepted - Prihvaćeno: 17.12.2017.

\begin{abstract}
Feed composition is one of the most influential factors affecting fatty acid profile of milk products. The aim of this study was to investigate the influence of linseed oil and linseed extrudate supplementation on fatty acid composition of goat prebiotic and probiotic yogurt drinks. Thirty six White Shorthaired dairy goats at the beginning of their third lactation period were divided into two experimental and one control group, each comprising twelve animals. Goats in the experimental groups were given either $55 \mathrm{~mL} /$ day of linseed oil or $120 \mathrm{~g} /$ day of linseed extrudate over a three week period. The results suggest that feed supplementation with linseed oil and linseed extrudate caused considerable changes in fatty acid profile of goat yoghurt drinks. The most important nutritional change which was observed was increased $n-3$ fatty acid content $(P<0.001)$ and decreased saturated fatty acid content $(\mathrm{P}<0.001)$. $\alpha$-linolenic acid was significantly elevated $(\mathrm{P}<0.001)$ in both groups (in particular in goats which feed was supplemented with linseed oil).
\end{abstract}

Key words: fatty acid, goat milk, $\alpha$-linolenic acid, linseed oil, linseed extrudate

\section{Introduction}

In recent years there is a growing interest in dairy foods which are able to provide positive health benefits. Such specific dairy commodities may include probiotic products made from goat milk high in $\mathrm{n}-3$ fatty acids (FA) and prebiotics. Probiotic bacteria demonstratedto benefit human health and are valued for their antimicrobial, antioxidant and immunomodulatory effects (Lee et al., 2011). On the other hand, prebiotics (such as oligosaccharides) are classified as more or less indigestible food constituents which could particularly impact the growth and activity of probiotic microorganisms in the gastrointestinal tract (Valcheva and Dieleman, 2016). Only five particular FA (C10:0, C14:0, C16:0,
C18:0 and C18:1) account for more than $75 \%$ FA present in goat milk (Park et al., 2007). Alternation of these FA could vastly benefit the consumer by increasing n-3 FA and decreasing specific mediumchain saturated fatty acids (SFA) found in goat milk. Such modifications could be achieved by using appropriate animal feed supplementation on the farm.

FA appearing in milk triacylglycerols originate from two distinct sources. The first one is the de novo synthesis which takes place in secretory cells of the mammary gland and produces all C4:0 to C12:0, $95 \%$ of C14:0 and about $50 \%$ C16:0. The circulating lipoproteins in blood plasma and the animal's fat reserves (which have their primary origin in the animal diet) are considered to be the second source

${ }^{*}$ Corresponding author/Dopisni autor: E-mail: borkovam@gmail.com 
of FA which supplies all C18:0 and higher FA found in milk (Shingfield et al., 2013).

Linseed (Linum usitatissimum L.), being also known as flax, is an excellent source of nutritionally valuable lipids (40-50 \% by weight) and n-3 FA (like the essential $\alpha$-linolenic acid) which makes it a good feed supplement to achieve modifications of milk fat composition. For example, if humans take $\alpha$-linolenic acid (ALA) then it undergoes elongation and desaturation in the body to produce docosahexaenoic (DHA) and eicosapentaenoic (EPA) acids which have been shown to reduce blood pressure, blood triglycerides, inflammation and the incidence of cardiovascular diseases (Cloutier, 2016).

The purpose of this study was to investigate the quantities of ALA and other n-3 FA found in goat yoghurt drinks made after the goat feed had been supplemented with linseed oil or linseed extrudate.

\section{Materials and methods}

\section{Animals and animal diet}

The experiment was carried out on a private organic farm near Liberec (Czech Republic). From 150 White Shorthaired dairy goats, thirty six (before their third lactation) were selected based on age (3 years), date of kidding (during March 2016) and litter size (2 kids) and randomly divided into three groups, two experimental (LO, LE) and one control (C), each comprising twelve animals. The goats were housed indoors and their feed consisted of: hay (ad libitum), grass (1.5 kg/animal/day), haylage $(1.5 \mathrm{~kg} / \mathrm{animal} /$ day) and grain mix of $50 \%$ corn, $25 \%$ barley and $25 \%$ oat (300 g/animal/day).

During the three-week experiment (June 7 through June 29, 2016) goats in the LO group were fed basic ration supplemented with $55 \mathrm{~mL}$ of linseed oil (LO) per animal/day whereas LE group was supplemented with $120 \mathrm{~g}$ of linseed extrudate (LE) containing $42.3 \%$ fat per animal/day. LO and LE were supplied by 1. zemědělská a.s. (Chorušice, Czech Republic). The C group was fed the same diet without LO/LE supplements. The individual milk samples to make yoghurt drinks were taken the last day of the experiment during the morning milking.

\section{Chemical analysis of animal diet}

The animal diet was analysed according to methods published in the Official Journal of the European Union in the Commission Regulation 152/2009 for the total dry matter (DM), ash, crude protein (CP), ether extract (EE) and crude fiber (CF). The FA analysis including lipid extraction was carried out as described by Kubelková et al. (2013). Results are presented in Table 1.

Table 1. Composition of basic diet, linseed oil and linseed extrudate

\begin{tabular}{|c|c|c|c|c|c|c|}
\hline & Hay & Grass & Haylage & Grain mix & Linseed oil & $\begin{array}{c}\text { Linseed } \\
\text { extrudate }\end{array}$ \\
\hline $\mathrm{DM}^{1}\left(\mathrm{~g} / 100 \mathrm{~g} \mathrm{FW}^{2}\right)$ & 88.1 & 23.7 & 33.3 & 88.6 & - & - \\
\hline Crude protein ${ }^{3}$ (g/100 g DM) & 7.16 & 19.2 & 14.5 & 9.19 & - & - \\
\hline Ether extract ${ }^{4}$ (g/100 g DM) & 0.67 & 1.63 & 1.36 & 1.51 & - & - \\
\hline Crude fibre (g/100 g DM) & 39.8 & 26.9 & 26.4 & 6.06 & - & - \\
\hline Ash (g/100 g DM) & 5.13 & 9.40 & 7.80 & 14.1 & - & - \\
\hline \multicolumn{7}{|l|}{ FA composition (g/100 g FA): } \\
\hline SFA $^{5}$ & 30.1 & 25.3 & 31.6 & 27.7 & 9.89 & 10.4 \\
\hline MUFA $^{6}$ & 42.5 & 16.1 & 29.5 & 19.4 & 16.5 & 16.6 \\
\hline PUFA $^{7}$ & 27.3 & 58.6 & 38.9 & 52.9 & 73.6 & 73.0 \\
\hline n-6 FA & 16.3 & 15.9 & 22.1 & 45.6 & 16.7 & 19.2 \\
\hline$n-3$ FA & 10.9 & 42.1 & 16.6 & 7.01 & 56.9 & 53.7 \\
\hline ALA $^{8}$ & 10.0 & 41.3 & 15.9 & 6.09 & 56.9 & 53.7 \\
\hline
\end{tabular}

${ }^{1} \mathrm{DM}$ - dry matter; ${ }^{2} \mathrm{FW}$ - fresh weight: ${ }^{3}$ nitrogen content - N $\times 6.25 ;{ }^{4} \mathrm{crude}$ fat; ${ }^{5}$ saturated fatty acid; ${ }^{6}$ monounsaturated fatty acid; ${ }^{7}$ polyunsaturated fatty acid; ${ }^{8} \alpha$-linolenic acid 


\section{Yoghurt drinks}

Thirty six individual milk samples were taken to the laboratory and used to produce 36 yoghurt drinks. The milk was analysed for fat, protein, lactose and total solids (Table 2) by an IR milk analyzer DairySpec FT (Bentley Instruments, Inc.). Four grams of chicory based inulin prebiotics (Orafti P95, Beneo-Orafti) were added into $196 \mathrm{~g}$ of goat milk, pasteurized at $84^{\circ} \mathrm{C}$ for $10 \mathrm{~min}$ and fermented using CCDM 528 (Streptococcus themophilus and Lactobacillus delbruckii subsp. bulgaricus, Laktoflora ${ }^{\circledR}$ ) and Bifidobacterium animalis subsp. lactis (Bb12, Chr. Hansen) at $30{ }^{\circ} \mathrm{C}$ for 16-18 h. Inulin and Bifidobacterium animalis subsp. lactis were added into the goat yoghurt drink to improve nutritional and sensory qualities.

\section{Fatty acid analysis}

The fat in the yoghurt drinks was extracted according to ČSN EN ISO 1211. FA were then re-esterified into the corresponding methyl esters (FAME) according to a modified method by Simionato et al. (2010). Approximately $40 \mathrm{mg}$ of milk fat was weighed into a thick walled tube and $0.5 \mathrm{~mL}$ methanol and $0.5 \mathrm{~mL}$ sodium methanolate $(0.5 \mathrm{M})$ were added. The solution was shaken vigorously for $1 \mathrm{~min}$ and heated for $2 \mathrm{~min}$ at $80^{\circ} \mathrm{C}$. Next, $1.5 \mathrm{~mL}$ of hexane and $10 \mathrm{~mL}$ of saturated sodium chloride solution were added and the tubes shaken again for $1 \mathrm{~min}$. The FAME were analyzed by gas chromatography (GC parameters shown in Table 3). Thirty seven FAME were identified using external analytical standards (Supelco, USA). The content of a particular FA was calculated as a ratio of its peak area/sum of all FA peak areas and given in $\mathrm{g} / 100 \mathrm{~g}$ total FA.

\section{Statistical analysis}

The data were analysed in Statistica (ver. 12, StatSoft, Inc). Milk yield, milk composition and the FA were tested by one-way ANOVA (LO or LE being categorical variables). Tukey's post-hoc HSD test $(\mathrm{P}<0.05)$ was used to evaluate differences between groups. Results are expressed as mean value with the standard error of mean (SEM).

Table 2. Milk yield and milk composition

\begin{tabular}{cccccc}
\hline & $\mathrm{C}^{1}$ & $\mathrm{LE}^{2}$ & $\mathrm{LO}^{3}$ & $\mathrm{SEM}^{4}$ & P value \\
\hline Milk yield $(\mathrm{kg} /$ day $)$ & 1.55 & 1.79 & 1.78 & 0.06 & $\mathrm{NS}$ \\
\hline Milk fat $(\mathrm{g} / 100 \mathrm{~g})$ & 3.16 & 3.06 & 3.40 & 0.08 & $\mathrm{NS}$ \\
\hline Milk protein $(\mathrm{g} / 100 \mathrm{~g})$ & 2.96 & 2.94 & 2.96 & 0.02 & $\mathrm{NS}$ \\
\hline Total solids $(\mathrm{g} / 100 \mathrm{~g})$ & 11.3 & 11.4 & 11.8 & 0.11 & $\mathrm{NS}$ \\
\hline
\end{tabular}

NS not found to be significantly different $(\mathrm{P}>0.05)$.

${ }^{1}$ control group $(\mathrm{N}=12)$; ${ }^{2}$ goats fed linseed extrudate $(\mathrm{N}=12) ;{ }^{3}$ goats fed linseed oil $(\mathrm{N}=12) ;{ }^{4}$ standard error of mean

Table 3. GC parameters

\begin{tabular}{cc}
\hline Parameter & Value \\
\hline GC & Agilent 7890A \\
\hline Detector & FID \\
\hline Column & SP-2560; $100 \mathrm{~m} \times 0.25 \mathrm{~mm} \times 0.2 \mu \mathrm{m}$; Supelco \\
\hline Column temperature gradient & $140^{\circ} \mathrm{C}$ for $5^{\circ} \mathrm{C}$ \\
& $4{ }^{\circ} \mathrm{C} . \min ^{-1}$ up to $245^{\circ} \mathrm{C}$ \\
$20^{\circ}$ min hold at $245^{\circ} \mathrm{C}$ \\
\hline Injection temperature & $280^{\circ} \mathrm{C}$ \\
\hline Detector temperature & $280^{\circ} \mathrm{C}$ \\
\hline Helium flow & $1.2 \mathrm{~mL} \cdot \mathrm{min}^{-1}$ \\
\hline Injection & $1 \mu \mathrm{L} ;$ split ratio $1: 100$ \\
\hline
\end{tabular}




\section{Results and discussion}

For a long time, it has been known that linseed is a very good source of n-3 FA and ALA. In our experiment we wanted to prove the hypothesis that feeding linseed derived supplements (in two different forms) to goats on a farm will eventually lead to alterations in FA profile of the milk thus adding health benefits to the resulting dairy products. Regular feed (grass, hay, haylage and grain mix) given to goats contained only very small amounts of fat (0.7-1.6 \%) of which 6-41.3\% were ALA (similar percentage was found for $n-3$ FA as well) making the intake of n-3 FA or ALA from the regular feed small. Our analyses of FA in LO and LE (Table 1) have shown that both, when used as supplements, are important sources of n-3 FA. LO and LE contained $56.9 \%$ and $53.7 \%$ ALA in fat, respectively.

Table 2 shows the impact of linseed products on average milk yield and composition. No other significant differences were found in milk yield and composition regarding the fat content, protein, and total solids among the three groups. On the other hand, feed supplementation with linseed products significantly impacted the FA profile of yogurt drinks (Table 4) made from milk from the two experimental (LO and LE) groups. These results are discussed in greater detail below.

Table 4. Fatty acid composition of goat yoghurt drinks (g/100 g total FA)

\begin{tabular}{|c|c|c|c|c|c|}
\hline FA & $\mathrm{C}^{1}$ & $\mathrm{LO}^{2}$ & $\mathrm{LE}^{3}$ & $\mathrm{SEM}^{4}$ & $P$ value \\
\hline $\mathrm{C} 4: 0$ & 2.33 & 2.40 & 2.44 & 0.031 & NS \\
\hline C6:0 & $2.58^{\mathrm{a}}$ & $2.61^{\mathrm{a}}$ & $2.40^{\mathrm{b}}$ & 0.030 & $\mathrm{P}<0.01$ \\
\hline $\mathrm{C} 8: 0$ & $2.77^{\mathrm{a}}$ & $2.82^{a}$ & $2.39^{\mathrm{b}}$ & 0.053 & $\mathrm{P}<0.001$ \\
\hline $\mathrm{Cl0:0}$ & $9.11^{\mathrm{a}}$ & $9.25^{\mathrm{a}}$ & $7.32^{\mathrm{b}}$ & 0.205 & $\mathrm{P}<0.001$ \\
\hline $\mathrm{Cl2:0}$ & $3.75^{\mathrm{a}}$ & $3.60^{\mathrm{a}}$ & $2.78^{\mathrm{b}}$ & 0.096 & $\mathrm{P}<0.001$ \\
\hline $\mathrm{Cl} 4: 0$ & $10.2^{\mathrm{a}}$ & $9.08^{\mathrm{b}}$ & $8.39^{c}$ & 0.158 & $\mathrm{P}<0.001$ \\
\hline Cl6:0 & $27.5^{\mathrm{a}}$ & $24.5^{\mathrm{b}}$ & $24.1^{\mathrm{b}}$ & 0.349 & $\mathrm{P}<0.001$ \\
\hline $\mathrm{Cl} 8: 0$ & $8.71^{\mathrm{b}}$ & $8.79^{b}$ & $11.6^{\mathrm{a}}$ & 0.298 & $\mathrm{P}<0.001$ \\
\hline$t-\mathrm{Cl} 18: 1^{5}$ & $1.69^{c}$ & $4.83^{\mathrm{a}}$ & $4.18^{\mathrm{b}}$ & 0.247 & $\mathrm{P}<0.001$ \\
\hline c9-C18:1 & $20.0^{\mathrm{a}}$ & $16.0^{\mathrm{b}}$ & $20.5^{a}$ & 0.411 & $\mathrm{P}<0.001$ \\
\hline$t-\mathrm{Cl} 8: 2^{6}$ & $0.74^{\mathrm{c}}$ & $2.52^{\mathrm{a}}$ & $1.76^{\mathrm{b}}$ & 0.130 & $\mathrm{P}<0.001$ \\
\hline$c 9, c 12-\mathrm{Cl} 18: 2$ & $2.78^{\mathrm{b}}$ & $3.20^{\mathrm{a}}$ & $2.87^{\mathrm{b}}$ & 0.052 & $\mathrm{P}<0.01$ \\
\hline$c 6, c 9, c 12-\mathrm{C} 18: 3$ & 0.028 & 0.027 & 0.025 & 0.001 & NS \\
\hline$c 9, c 12, c 15-\mathrm{Cl} 8: 3$ (ALA) & $1.08^{\mathrm{c}}$ & $2.56^{\mathrm{a}}$ & $1.92^{\mathrm{b}}$ & 0.116 & $\mathrm{P}<0.001$ \\
\hline CLA $^{7}$ & $0.50^{c}$ & $0.83^{\mathrm{a}}$ & $0.67^{\mathrm{b}}$ & 0.027 & $\mathrm{P}<0.001$ \\
\hline$c 11, c 14-C 20: 2$ & $0.039^{c}$ & $0.072^{\mathrm{a}}$ & $0.054^{\mathrm{b}}$ & 0.002 & $\mathrm{P}<0.001$ \\
\hline$c 8, c 11, c 14-C 20: 3$ & $0.022^{\mathrm{a}}$ & $0.015^{b}$ & $0.015^{b}$ & 0.001 & $\mathrm{P}<0.001$ \\
\hline$c 11, c 14, c 17-C 20: 3$ & $0.027^{\mathrm{a}}$ & $0.016^{\mathrm{b}}$ & $0.022^{\mathrm{a}}$ & 0.001 & $\mathrm{P}<0.01$ \\
\hline$c 5, c 8, c 11, c 14-\mathrm{C} 20: 4$ & $0.14^{\mathrm{a}}$ & $0.11^{\mathrm{b}}$ & $0.11^{\mathrm{b}}$ & 0.004 & $\mathrm{P}<0.001$ \\
\hline$c 13, c 16-C 22: 2$ & $0.007^{c}$ & $0.010^{\mathrm{a}}$ & $0.008^{\mathrm{b}}$ & 0.000 & $\mathrm{P}<0.001$ \\
\hline$c 5, c 8, c 11, \mathrm{cl} 4, \mathrm{cl} 7-\mathrm{C} 20: 5$ & 0.088 & 0.096 & 0.099 & 0.002 & NS \\
\hline$c 4, c 7, c 10, c 13, c 16, c 19-\mathrm{C} 22: 6$ & $0.075^{\mathrm{a}}$ & $0.054^{\mathrm{b}}$ & $0.059^{b}$ & 0.002 & $\mathrm{P}<0.01$ \\
\hline c9-C18:1/C18:08 & $2.31^{\mathrm{a}}$ & $1.84^{\mathrm{b}}$ & $1.78^{\mathrm{b}}$ & 0.051 & $\mathrm{P}<0.001$ \\
\hline $\mathrm{SFA}^{9}$ & $70.0^{\mathrm{a}}$ & $65.8^{\mathrm{b}}$ & $64.1^{\mathrm{b}}$ & 0.531 & $\mathrm{P}<0.001$ \\
\hline MUFA $^{10}$ & $24.5^{\mathrm{b}}$ & $24.7^{\mathrm{b}}$ & $28.3^{a}$ & 0.390 & $\mathrm{P}<0.001$ \\
\hline PUFA $^{11}$ & $5.52^{\mathrm{c}}$ & $9.50^{\mathrm{a}}$ & $7.61^{\mathrm{b}}$ & 0.299 & $\mathrm{P}<0.001$ \\
\hline$n-6$ FA & $3.02^{\mathrm{b}}$ & $3.43^{\mathrm{a}}$ & $3.08^{\mathrm{b}}$ & 0.053 & $\mathrm{P}<0.01$ \\
\hline$n-3$ FA & $1.27^{\mathrm{c}}$ & $2.72^{a}$ & $2.10^{\mathrm{b}}$ & 0.115 & $\mathrm{P}<0.001$ \\
\hline
\end{tabular}

Different small caps in superscript indicate differences between groups $(\mathrm{P}<0.05)$, NS not found to be significantly different $\mathrm{P}>0.05)$ ${ }^{1}$ control group $(\mathrm{N}=12) ;{ }^{2}$ goats fed linseed extrudate $(\mathrm{N}=12) ;{ }^{3}$ goats fed linseed oil $(\mathrm{N}=12) ;{ }^{4}$ standard error of mean;

${ }^{5}$ trans isomers C18:1 (including e.g. vaccenic acid; $t 11-C 18: 1$ ); ${ }^{6}$ trans isomers C18:2 (including e.g. $t 11, c 15-C 18: 2$ );

${ }^{7}$ conjugated linoleic acid (mixture of isomers $c 9 t 11-\mathrm{C} 18: 2$ and $t 9 c 11-\mathrm{C} 18: 2$ ); ${ }^{8}$ desaturase index; ${ }^{9}$ saturated fatty acid;

${ }^{10}$ monounsaturated fatty acid; ${ }^{11}$ polyunsaturated fatty acid 


\section{Saturated fatty acids}

In our experiment, feed supplementation with LO and LE significantly decreased SFA in yogurt drinks (both $\mathrm{P}<0.001$ ). In accordance to the data published for goat milk in the scientific literature (Bernard et al., 2009; Martínez Marín et al., 2011; Nudda et al., 2006 and 2013), our results showed a decrease in medium-chain SFA (C14:0 and $\mathrm{Cl6}$ :0, $\mathrm{P}<0.001$ ) in yogurt drinks made from LO and LE groups. In addition, LE supplementation was able to reduce short-chain SFA in drinks (in particular C6:0, $\mathrm{P}<0.05 ; \mathrm{C} 8: 0, \mathrm{P}<0.01 ; \mathrm{C} 10: 0$, $\mathrm{P}<0.001)$. Martínez Marín et al. (2011) and Nudda et al. (2006) reported that short-chain FA (C6:0 to $\mathrm{C10:0)}$ remained unchanged after the addition of LO or LE into the feed whereas Bernard et al. (2009) and Nudda et al. (2013) observed a decline. The reduction of short- and medium-chain SFA may have been caused by two factors. The first one was the shortage of acetate and 3-hydroxybutyrate substrates in blood plasma used for the de novo synthesis in mammary gland which can be the consequence of alterations in rumen microflora caused by the high-fat diet. The other factor for the reduction of short- and medium-chain SFA might have been the increased intake of long-chain polyunsaturated fatty acids (PUFA) which affected crucial enzymes in the de novo pathway such as acetylCoA carboxylase and fatty acid synthase (Martínez Marín et al., 2011).

The results from our experiment revealed an increased content of C18:0 in LE drinks $(\mathrm{P}<0.001)$. Both, LE as well as LO, are rich in PUFA (predominantly in ALA) which are extensively metabolized and hydrogenated in rumen to form C18:0 FA. Thus, this particular transformation pathway might have led to the increased C18:0 content found in LE drinks. Similar results were found in milk after feeding LE to goats (Bernard et al., 2015; Renna et al., 2013; Nudda et al., 2006; Nudda et al., 2013). Interestingly, no increase in C18:0 was found in LO drinks. This corresponds to the results published by Martínez Marín et al. (2012) who supplemented the feed with 48 or $66 \mathrm{~g}$ of LO for 15 days and found no increase in C18:0. On the contrary, when only half of the LO was fed, the same authors registered an increase in C18:0. Accordingly, it is evident that the amount of PUFA and the form in which PUFA are added to the feed does influence the biohydro- genation in rumen. It is likely that the unprotected PUFA (from LO) have caused major alternations in rumen microflora and thus the PUFA hydrogenation was inhibited. This can be shown by the differences in C18:0 concentrations between LO and LE drinks.

\section{Monounsaturated fatty acids}

The addition of LO significantly reduced $c 9$ C18:1 content $(\mathrm{P}<0.001)$ in drinks. More than $50 \%$ of $c 9-\mathrm{Cl} 8: 1$, which is secreted into the milk, is synthesized in the mammary gland from C18:0 by stearoyl-CoA desaturase (Renna et al., 2013). LO is an important source of ALA which can lead to the formation of C18:0 but also can be utilized to form large amounts of PUFA and MUFA isomers like $t 11-C 18: 1$ (vaccenic acid), $t 11, c 15-C 18: 2$ and $c 9, t 11, c 15-C 18: 3$. It was found that certain hydrogenation intermediates could act as regulators or disruptors of mammary lipogenesis altering the amounts of milk fat and its composition (Chilliard et al., 2007). It is likely that some of these intermediates may also inhibit stearoyl-CoA desaturase.

Our results indicate that LO drinks had a lower desaturation index $c 9-\mathrm{C} 18: 1 / \mathrm{C} 18: 0$ of $1.84 \%$ compared to the control sample $(2.31 \%$ in $\mathrm{C}$; $\mathrm{P}<0.001)$. The same phenomenon was also observed for LE drinks (1.78\%; $\mathrm{P}<0.001)$ in which $c 9-\mathrm{C} 18$ :1 content did not decrease. As mentioned before, LE drinks had significantly higher levels of C18:0 and the decrease in $c 9-\mathrm{C} 18: 1$ did not occur probably due to greater $\mathrm{C} 18: 0$ availability in the mammary gland for the $c 9-\mathrm{Cl} 8: 1$ synthesis.

LO and LE supplementation increased the content of trans-C18:1 isomers in drinks $(\mathrm{P}<0.001$; in both). These results were in accordance with findings of Martínez Marín et al. (2011), Bernard et al. (2009; 2015) and Nudda et al. (2013) who also observed a similar increase after LO and LE supplementation. The increase of trans-C18:1 isomers in yogurt samples was probably caused by the elevated ALA hydrogenation. However, it is necessary to underscore that trans-FA in food products could have negative impact on consumer health even though this has not been the case of all trans-FA (Anadón et al., 2010; Jacome-Sosa et al., 2014; Ganguly and Pierce, 2015). This also applies to vaccenic acid which is the main hydrogenation intermediate of ALA present in milk. The increase in trans-C18:1 
isomers caused a statistically significant increase of MUFA in LE drinks $(\mathrm{P}<0.001)$. In the case of LO drinks, despite the increase in trans-C18:1 isomers due to the decrease of $c 9-\mathrm{Cl} 8: 1$ (as it has been described above), the increase in MUFA was not observed.

\section{Polyunsaturated fatty acids}

Higher contents of PUFA and n-3 FA were found in $\mathrm{LO}$ and $\mathrm{LE}$ drinks $(\mathrm{P}<0.001$ in all cases). Supplementation with LO and LE did indeed significantly increase ALA in both types of drinks $(\mathrm{P}<0.001$ in both) because due to the LO/LE supplementation the feed contained already high amounts of ALA. Thus, in our experiment, LO drinks contained statistically higher amounts of ALA $(\mathrm{P}<0.001)$ then LE drinks. These results are consistent with the findings published by Chilliard et al. (2003) who reported that daily addition of $3.4 \% \mathrm{LO}$ to the feed significantly increases ALA in goat milk (even more than the same amount of ALA in the form of LE did when it was tested). Chilliard et al. (2003) found that the biohydrogentation in rumen was less efficient in case of LO than when using oilseeds. This assumption also explains higher contents of trans-C18:2 $(\mathrm{P}<0.001)$, conjugated linoleic (CLA; $\mathrm{P}<0.001)$ and linoleic acid $(\mathrm{LA} ; \mathrm{P}<0.01)$ in LO drinks compared to LE drinks. Higher contents of trans-C18:2 $(\mathrm{P}<0.001)$ and CLA $(\mathrm{P}<0.001)$ were also found in LE drinks. However, these amounts of trans-C18:2 and CLA were lower than those in LO drinks. In addition, supplementation with LO and LE also altered the quantities of other $n-3$ and n- 6 FA but since each of those FA accounted for less than $0.2 \%$ we refrain from commenting on those results because they have no nutritional significance for consumer's health.

\section{Conclusions}

Supplementing goat feed with LO and LE improved FA profile of dairy products by decreasing the content of medium-chain SFA and by increasing the n-3 FA as well. An important increase in ALA and n-3 FA was recorded in yoghurt drinks made from milk of goats fed LO rather than LE. It is evident that the particular source of PUFA influences significantly milk FA composition since LO had a better performance compared with LE containing the same amount of ALA. Nevertheless both feed supplements led to production of probiotic yoghurt drinks containing higher levels of n-3 FA and, thus, could be considered to benefit human health.

\section{Acknowledgements}

This research had been supported by The Czech Ministry of Agriculture RO1417 and the National Agency for Agricultural Research (NAZV) No. QJ1310107.

\section{Utjecaj obogaćivanja stočne hrane lanenim uljem i ekstrudatom sjemena lana na profil masnih kiselina u kozjem jogurtu}

\section{Sažetak}

Sastav krme jedan je od najznačajnijih čimbenika koji utječu na profil masnih kiselina mliječnih proizvoda. Cilj ovog istraživanja bio je istražiti utjecaj dodatka ulja lanenog sjemena ili ekstrudata lanenog sjemena na sastav masnih kiselina prebiotičkog i probiotičkog jogurta od kozjeg mlijeka. Trideset i šest mliječnih koza pasmine White Shorthaired na početku trećeg razdoblja laktacije podijeljene su u dvije eksperimentalne i jednu kontrolnu skupinu, od kojih svaka uključuje dvanaest životinja. Kozama u eksperimentalnim skupinama davano je $55 \mathrm{~mL} /$ dan ulja lanenog sjemena ili $120 \mathrm{~g} /$ dan ekstrudata lanenog sjemena tijekom tri tjedna. Dodatak ulja lanenog sjemena i ekstrudata lanenog sjemena izazvao je znatne promjene $u$ profilu masnih kiselina kozjeg jogurta. Najznačajnija promjena $\mathrm{u}$ hranjivim svojstvima bila je povećana količina masnih kiselina $\mathrm{n}-3(\mathrm{P}<0,001) \mathrm{i}$ smanjen udjel zasićenih masnih kiselina $(\mathrm{P}<0,001)$. Udjel $\alpha$-linolenske kiseline bio je značajno povišen $(\mathrm{P}<0,001)$ u obje skupine (posebno kod koza koje su hranjene dodatkom lanenog ulja).

Ključne riječi: masna kiselina, kozje mlijeko, $\alpha$-linolenska kiselina, ulje lanenog sjemena, ekstrudirano laneno sjeme 


\section{References}

1. Anadón, A., Martínez-Larrañaga, M.R., Martínez, M.A., Ares, I., Ramos, E., Gómez-Cortés, P., Juárez, M., De la Fuente, M.A. (2010): Acute oral safety study of dairy fat rich in trans-10 Cl8:1 versus vaccenic plus conjugated linoleic acid in rats. Food and Chemical Toxicology 48 (2), 591-598. https://doi.org/10.1016/j.fct.2009.11.037

2. Bernard, L., Shingfield, K.J., Rouel, J., Ferlay, A., Chilliard, Y. (2009): Effect of plant oils in the diet on performance and milk fatty acid composition in goats fed diets based on grass hay or maize silage. British Journal of Nutrition 101 (2), 213-224. https://doi.org/10.1017/S0007114508006533

3. Bernard, L., Leroux, C., Rouel, J., Delavaud, C., Shingfield, K.J., Chilliard, Y. (2015): Effect of extruded linseeds alone or in combination with fish oil on intake, milk production, plasma metabolite concentrations and milk fatty acid composition in lactating goats. Animal 9 (5), 810-821. https://doi.org/10.1017/S1751731114003048

4. Chilliard, Y., Ferlay, A., Rouel, J, Lamberet, G. (2003): A review of nutritional and physiological factors affecting goat milk lipid synthesis and lipolysis. Journal of Dairy Science 86 (5), 1751-1770. https://doi.org/10.3168/jds.S0022-0302(03)73761-8

5. Chilliard, Y., Glasser, F., Ferlay, A., Bernard, L., Rouel, J., Doreau, M. (2007): Diet, rumen biohydrogenation and nutritional quality of cow and goat milk fat. European Journal of Lipid Science and Technology 109, 828-855. https://doi.org/10.1002/ejlt.200700080

6. Cloutier, S. (2016): Linseed: Overview. In Encyclopedia of food grains - Corke, H., Wrigley, C., Seetharaman, K. and Faubion, J. (eds.), 2nd Edition, Elsevier, Oxford, UK, 259-264. https://doi.org/10.1016/B978-0-12-394437-5.00031-0

7. Commission Regulation (2009): Commission Regulation (EC) No 152/2009 of 27 January 2009 laying down the methods of sampling and analysis for the official control of feed. Official Journal of the European Union L54, 1-130. http://data.europa.eu/eli/reg/2009/152/oj

8. ČSN EN ISO 1211 (2011): Milk - Determination of fat content - Gravimetric method (Reference method). Czech office for standards, metrology and testing. Prague. http://seznamcsn.unmz.cz/Detailnormy.aspx?k=89462

9. Ganguly, R., Pierce, G.N. (2015): The toxicity of dietary trans fats. Food and Chemical Toxicology, 78, 170-176. https://doi.org/10.1016/j.fct.2015.02.004

10. Jacome-Sosa, M.M., Borthwick, F., Mangat, R., Uwiera, R., Reaney, M.J., Shen, J., Quiroga, A.D., Jacobs, R.L., Lehner, R., Proctor, S.D. (2014): Diets enriched in trans-11 vaccenic acid alleviate ectopic lipid accumulation in a rat model of NAFLD and metabolic syndrome. Journal of Nutritional Biochemistry 25 (7), 692-701. https://doi.org/10.1016/j.jnutbio.2014.02.011

11. Kubelková, P., Jalč, D., Homolka, P., Čermák, B. (2013): Effect of dietary supplementation with treated amaranth seeds on fermentation parameters in an artificial rumen. Czech Journal of Animal Science 58 (4), 159-166. https://www.researchgate.net/publication/286096771
12. Lee, J., Yun, H.S., Cho, K.W., Oh, S., Kim, S.H., Chun, T, Kim, B., Whang, K.Y. (2011): Evaluation of probiotic characteristics of newly isolated Lactobacillus spp.: Immune modulation and longevity. International Journal of Food Microbiology 148 (2), 80-86. https://doi.org/10.1016/j.ijfoodmicro.2011.05.003

14. Martínez Marín, A.L., Gómez-Cortés, P., Gómez Castro, A.G., Juárez, M., Pérez Alba, L.M., Pérez Hernández, M., de la Fuente, M.A. (2011): Animal performance and milk fatty acid profile of dairy goats fed diets with different unsaturated plant oils. Journal of Dairy Science 94 (11), 5359-5368. https://doi.org/10.3168/jds.2011-4569

15. Martínez Marín, A.L., Gómez-Cortés, P., Gómez Castro, G., Juárez, M., Pérez Alba, L., Pérez Hernández, M., de la Fuente, M.A. (2012): Effects of feeding increasing dietary levels of high oleic or regular sunflower or linseed oil on fatty acid profile of goat milk. Journal of Dairy Science 95 (4), 1942-1955. https://doi.org/10.3168/jds.2011-4303

16. Nudda, A., Battacone, G., Usai, M.G., Fancellu, S., Pulina, G. (2006): Supplementation with extruded linseed cake affects concentrations of conjugated linoleic acid and vaccenic acid in goat milk. Journal of Dairy Science 89 (1), 277-282. https://doi.org/10.3168/jds.S0022-0302(06)72092-6

17. Nudda, A., Battacone, G., Atzori, A.S., Dimauro, C., Rassu, S.P., Nicolussi, P., Bonelli, P., Pulina, G. (2013): Effect of extruded linseed supplementation on blood metabolic profile and milk performance of Saanen goats. Animal 7 (9), 1464-1471. https://doi.org/10.1017/S1751731113000931

18. Park, Y.W., Juárez, M., Ramos, M., Haenlein, G.F.W. (2007): Physico-chemical characteristics of goat and sheep milk. Small Ruminant Research 68, 88-113. https://doi.org/10.1016/j.smallrumres.2006.09.013

19. Renna, M., Lussiana, C., D Agostino, M., Mimosi, A., Fortina, R. (2013): Extruded linseed supplementation in dairy goat diet: Effects on productive performance and fatty acid profile of bulk milk, fresh and ripened cheese. Journal of Animal and Veterinary Advances 12 (20), 1550-1564. http://docsdrive.com/pdfs/medwelljournals/javaa/2013/1550-1564.pdf

20. Simionato, J.I., Garcia, J.C., dos Santos, G.T., Oliveira, C.C., Visentainer, J.V., de Souza, N.E. (2010): Validation of the determination of fatty acids in milk by gas chromatography. Journal of the Brazilian Chemical Society 21 (3), 520-524. h t t p://dx.doi.org/10.1590/S010350532010000300018

21. Shingfield, K.J., Bonnet, M., Scollan, N.D. (2013): Recent developments in altering the fatty acid composition of ruminant-derived foods. Animal 7, 132-162. https://doi.org/10.1017/S1751731112001681

22. Valcheva, R., Dieleman, L.A. (2016): Prebiotics: Definition and protective mechanisms. Best Practice \& Research: Clinical Gastroenterology 30 (1), 27-37. https://doi.org/10.1016/j.bpg.2016.02.008 